\title{
Between Christmas Day, 1895, and New Year's Eve, 1922: Queer Suicide and Brazil's Long Fin de Siècle
}

\author{
CÉSAR BRAGA-PINTO \\ Northwestern University
}

\begin{abstract}
This essay considers a heterogeneous and often unreadable group of fin-de-siècle Brazilian writers that includes Parnassians, Symbolists, and Decadents. These artists imagined themselves part of a cosmopolitan, transnational movement that posed as extravagant or queer, turning their back on both emerging nationalist sentiments and urgent social issues of their time. This detachment, I argue, points to a queer mode of historicity. I further argue that an affirmative rhetoric of hope and community is insufficient to understand or cope with negative figures, that is, those who turn away from social life, communication, and, ultimately, from futurity. I first focus on two queer fin-desiècle writers who committed suicide, Raul Pompeia (1863-95) and the playwright Roberto Gomes (1882-1922). I then propose that an archive of Brazilian "suicidals" may provide ways of reading these fin-de-siècle writers, as well as others who resist accommodation in the genealogy of national culture.
\end{abstract}

Keywords: Raul Pompeia, Roberto Gomes, decadence, suicidals, modernism

“Acho que é por isso que eu olho tanto pro vermelho que ele pintou aqui no álbum. Pra ver se eu entendo. Pra ver se eu entendo por que que tem gente que se mata" (Bojunga 19). 
"Sua fuga foi resultado do seu fracasso. De certo modo, ele se matou para sumir do seu campo de visão, para deixar de se ver" (Carvalho 112).

“O que é a vida senão uma sucessão de suicídios?” (Cruz).

In this essay, I revisit a heterogeneous and presumably unreadable group of fin-

de-siècle writers that includes Parnassians, Symbolists, and Decadents. Although they wrote from Brazil, these artists imagined themselves part of a cosmopolitan, transnational movement that posed as extravagant or queer. As such, they inhabited what Elisa Glick has called "queer sites of cultural production that helped to define both literary and sexual modernity" (325). Glick reminds us that European decadence and (British) aestheticism "sought to fashion a queer way of being in the world, expanding consciousness by embracing the fleeting sensations of life's restless motion" (326). And perhaps because, as Paul Bourget wrote, "[1]iteratures of decadent periods [...] have no tomorrow" (130), many of their writings have become unreadable to contemporary sensibilities. In what follows, I consider authors who turned away from life and the pressing problems of Brazilian society, authors who left no heirs or legacy. My approach to their writings resembles what Heather Love has called "an encounter with the illegible" ("Introduction" 747). I consider their presumed "detachment" alongside notions of cosmopolitanism and existential exile, and I explore their association with modern, queer experience and subjectivity in a nation where modernity was largely illusory. I then consider decadents' illegible legibility, that is, their legacy of non-legacy. I call these heirless writers "suicidals."

\section{Brazil's Long Fin de Siècle}

In Brazilian literature, the years preceding 1922 have variously been called prémodernismo, post-romanticism, the Belle Époque, and the First Republic, terms coined by or associated with critics like Tristão de Athaide, Antonio Candido, Brito Broca, and Nicolau Sevcenko, respectively. Since the mid-1980's, scholars like Flora Sussekind and Francisco Foot Hardman have paid renewed attention to this complex period, revealing the heterogeneity and contradiction of this alleged time of transition (Hardman 115). Indeed, the turn of the century encompassed styles, genres, and ideologies that ranged from belated Naturalism 
and Parnassianism to movements and trends known variously as decadismo or decadentismo, Symbolism, penumbrismo, crepuscularismo, bohemianism, impressionism, spiritualism, Francophilia, mundanismo, picturesque regionalism, and anarchism, not to mention the popular semi-pornographic novels that Alessandra El Far has recovered, known as romances de sensação and livros para homens, that is, books "to be read in only one hand" (Goulemot). The period also witnessed a proliferation of memoirs, reportage, comic magazines, and other so-called frivolities, as well as countless essays and monographs by ultra-nationalists, positivists, and others.

For much of the twentieth century, this literature was understood primarily under a rubric of failure or underachievement. An authoritative history of Brazilian literature calls Parnassians "alienados na pátria" and an "ilha dentro da ilha" (Stegagno Picchio 317). In 1950, Antonio Candido argued that writers of the period - in unfavorable contrast to romantic and modernist writers-failed to strike what he considered an ideal balance between nationalism and cosmopolitanism, or European form and local substance ("Literatura e cultura" 110). Candido calls 1922 the beginning of twentieth-century literature, and he characterizes the preceding two decades by an "amaciamento do diálogo e a consequente atenuação da rebeldia" that produced "uma literatura satisfeita, sem angústia formal, sem rebelião nem abismos" ("Literatura e cultura" 112). According to Candido, writers during this period lacked originality and primarily imitated metropolitan ideals: “[s]ua única mágoa é não parecer todo europeia; seu esforço mais tenaz é conseguir pela cópia o equilíbrio e a harmonia, ou seja, o academismo" ("Literatura e cultura" 113). He concludes, disparagingly, that "[a]s letras, o público burguês e o mundo oficial se entrosavam numa harmoniosa mediania" ("Literatura e cultura" 119); however, he does point out a few notable exceptions, such as Alphonsus de Guimarães (1870-1921), Augusto dos Anjos (1884-1914), Euclides da Cunha (1866-1909), and Lima Barreto (1881-1922). At the center of Candido's critique is the idea that fin-de-siècle writers in Brazil - in contrast to the "committed literature" that preceded and followed them-lacked interest in the nation and the world around them. Because they were so uninterested, they became uninteresting.

To be fair, Candido does work elsewhere to rescue another, albeit limited, group of writers from this period. He calls them "radicais de ocasião," a category of artists with no real commitment to social change who nonetheless, on occasion 
and in isolation, managed to behave in a way consistent with revolutionary ideals. Among these "radicais de ocasião," Candido highlights the early work of João do Rio (b. Paulo Barreto, 1881-1921), who emulated Oscar Wilde and shared Wilde's ability to demonstrate a profound (if fleeting) concern for social justice, "um átimo de sentimento radical" ("Radicais" 92) and sometimes even a "solidariedade intensa em relação ao operário" ("Radicais" 93). In language that recalls the fin de siècle's juridical and psychopathological terminology, Candido charts the period's cultural productions in relation to its writers' various degrees of "interestedness" and social commitment, the same qualities that he uses to define authentic nationality. As a result, he dismisses most of the work of João do Rio, one of the most prolific and intriguing writer-journalists of the early twentieth century.

Antonio Arnoni Prado recasts Candido's "radicais de ocasião" as the first examples of a "falsa vanguarda" (601). For Prado, the years that preceded Brazilian modernism merely reflected bourgeois tastes for novelty and consumerism, as the professionalization of the writer turned into sheer "officialdom," and nationalism and cosmopolitanism became two faces of the same "reformist project." As this reformist project fell into crisis, he argues, "a rebeldia dos insubmissos dará um matiz refinado ao exibicionismo dessa falsa vanguarda" (601). As for João do Rio, Prado dismisses his apparent nonconformity as a product of his elitism, sense of superiority, "desprezo pelo atraso cultural," and "adesão a um projeto de reconstrução desvinculado das necessidades reais do país" (608). Prado sees a disconnection between the writer's subject position and the role he was urged to play in solving the gravest problems of his time: “o projeto de João do Rio é no entanto um projeto de concepção linear que não se ajusta às tensões mais agudas da época senão a partir de seus privilégios de classe" (610). He further likens João do Rio's project to the aristocratic stance of some of his protagonists: "personagem curinga saída da aristocracia que vê o mundo de cima e atravessa as suas vicissitudes sem cruzar com o rosto desconhecido da plebe" (610). Finally, Prado contrasts aristocratic writers like João do Rio with Lima Barreto (1881-1922): "a revolta intelectual do mulato pobre do subúrbio que se recusa a reproduzir o estilo afetado dos literatos da época, em nome de uma solidariedade de classe que o aproxima dos oprimidos de toda sorte" (611).

Other critics have taken different approaches to João do Rio, Lima Barreto, 
and the groups they have come to represent. Antonio Dimas divides fin-de-siècle writers into two groups: jecas ("bumpkins") and janotas ("bougies"), and he sees João do Rio as a prototypical janota (537). He also considers Lima Barreto (along with Euclides da Cunha) to be an exception among his contemporaries: "Lima Barreto criava seu próprio caminho ao se voltar para as classes humildes e ao investigar o espaço urbano periférico do Rio de Janeiro" (561). Luciana Stegagno Picchio, however, reminds us that parnasianos, "apesar de sua estética alienada, não eram alienados, se é verdade que lhes cabe o mérito de terem reorganizado a vida intelectual do país em formas mais prestigiosas, também sob o ângulo social" (334). She also argues that the Symbolists were often as participante as Parnassians, if not more: "revoltados e incompreendidos num país de oposição e interação racial, social e cultural" (347). As for João do Rio, Stegagno Picchio classifies him among those Lúcia Miguel Pereira once called sorridentes (436). In contrast, Raúl Antelo summarized the paradoxes of João do Rio's modernity (or, in Mariano Siskind's terms, his "cosmopolitan desires") as follows: "Submisso ao establishment do qual, até certo ponto é sócio, não deixa, entretanto, de julgar-se superior ao Mercado, de que afinal depende" ("Introdução" 14).

Rather than rescue João do Rio and his contemporaries, I wish to invest renewed interest in some of these failed or uninterested writers by reconsidering the possible significance and potentialities of their so-called detachment from pressing socio-political demands. I begin by referring to Gerard Aching's work on modernismo (ca.1888-1914), which-significant differences in the texts, contexts, and travels of Spanish American writers notwithstanding - offers some hints for a revision of the critical contradictions and dead ends that characterize the period that I call Brazil's "long fin de siècle." Aching challenges simplistic allegations of escapism or evasive detachment, claiming that the modernistas "distanced themselves from autochthonous and popular cultural expressions" to withdraw to the "internal realm or space" of the "ivory tower" (22). Drawing on studies such as Julio Ramos's seminal Desencuentros de la modernidad en América Latina (which argues, inter alia, that modernistas expressed a certain autonomy in response to the demands of the market), Aching conceives of "detachment as an assertive engagement, that is to say, as the will to embellish 
from a precise cultural and discursive location" (3). ${ }^{1}$ For him, "[t]hese artists and intellectuals cultivated their exquisite literary style precisely to generate a particular reciprocity with their reading public [...]; they provided Spanish American ruling classes with works containing and promoting utopian alliances that served to affirm or transcend national boundaries" (18-19). This was part of a project of "forging a culture" (154) through invocation of "a pure and autonomous cultural meaning" (158), which, he concedes, was not devoid of elitism or racism. ${ }^{2}$ Aching's study does not explicitly deal with issues of sexuality; however, the terms of his argument anticipate some of the central concerns of queer theory over the last decade, namely, notions of queer detachment and utopianism. Indeed, Aching's interest in Fredric Jameson's "affirmation of collective solidarity" (291) as a way to reconsider the political valance of modernista writings brings to mind more recent debates around queer relationality and utopianism, particularly as formulated by critics such as José Esteban Muñoz in Cruising Utopia.

More recently, Anglophone critics have alternately associated the notion of detachment with decadentism and queerness, and occasionally with both (Price). These critics have attempted to reformulate the political significance of fin de siècle detachment by highlighting moments when detachment operates as a form of resistance against capitalist modernity. Amanda Anderson argues that cultivated or critical detachment can function as both a threat and a promise, and in some cases, it can offer particular ways of participating in communal life and even imagining communities outside the nation. Love considers refusal and other "forms of failure that are less closely tied to action" (Feeling Backwards 161). And as mentioned earlier, Glick's concise and illuminating account traces a number of significant challenges to the alleged lack of political commitment of decadence and other fin-de-siècle movements, challenges that consider their contradictory relationship to capitalist modernity. Put briefly, Glick's account of fin-de-siècle culture coincides with Ramos's and Aching's understanding of the modernista desire for autonomy. Glick therefore concludes:

\footnotetext{
${ }^{1}$ In the same year that Ramos published his study, Antelo published his groundbreaking work on João do Rio. In a parallel way, Antelo deals with the professionalization of writing, the crônica, and the cosmopolitan nature of the Belle Époque in Rio de Janeiro.

${ }^{2}$ This begs one to read, for example, Olavo Bilac's nationalist prose alongside his Parnassian poetry-that is, his political writing alongside his crowd-pleasers, notwithstanding claims regarding his ivory-tower, art-for-art's-sake aesthetics.
} 
Decadence's luxurious extravagance refuses the rationalization and utilitarianism of capitalism's restricted economy, producing a convergence of aesthetics and sexuality that is inextricably linked to the market but never fully contained by it. [...] Decadence's negativity is not simply pessimistic or nihilistic; its reified universe contains within it a utopian possibility. (338)

In spite of such arguments, critics have largely been unable to reconcile the antisocial and nihilistic dimensions of fin-de-siècle decadence. Some, such as Muñoz, emphasize the utopian impulse at work in decadence, while others, like Edelman, remain impressed by its anti-social nihilism.

I am more inclined toward Edelman's stance; however, I am nevertheless interested in the affirmative and sometimes joyful undertones of the utopian interpretation. In what follows, I examine the works of two writers of Brazil's long fin de siècle, Raul Pompeia and Roberto Gomes, both of whom have been associated with different forms and degrees of political and/or aesthetic detachment. I do not mean to minimize the political dangers inherent in any attempt to reevaluate their work; nonetheless, by considering not only gestures of partial or complete detachment-refusal, failure, alienation, distance, or abstentionism - but also "a politics that allows for damage" (Love, "Looking Backwards" 162), I wish to reclaim a corpus of unrecognized postures and posturing stripped of significance by the national archive. In particular, I am concerned with stances that reject hope in any form and thereby approach the most radical, and perhaps most unreadable, expression of (queer) detachment: the thought of suicide.

\section{Radical Detachment}

Beginning an essay that is for many readers at once comforting and disturbing, Love speaks of her personal history: "It used to be that I talked about my gay shame with only my friends - and then, really, only with my close friends. This shame took many forms, but it came out most often as ambivalence about myself and 'others like me"" ("Emotional Rescue" 257). Love describes this personal and collective ambivalence as a "range of boomeranging feelings," and she locates herself among a group of scholars who were then (some ten-plus years ago) starting to consider the productive potential of shame or, in the words of another scholar, to articulate "collectivities of the shamed" (Crimp 66). Love's 
distinction between "shameproof institutions" and "shame prone" groups or individuals is particularly useful, as is the way that she, after Eve Sedgwick, tries to comprehend both the potential and the (political and other) limitations of the "uncontrollable relationality of shame," insofar as "[n]ot all aspects of queer experience are productive" (258). Love proposes that we understand "shame" as one of "a range of negative affects produced by the experience of social exclusion: self-loathing, anger, sadness, fear, the sense of failure, envy, despair, longing, loneliness - or resistance to community altogether" (258). She further urges her readers to exercise caution in trying to rescue the (gay) past, and in trying to be rescued by it; as she sees it, we must be wary of thinking that we hear what "queer subjects want to hear from their imagined ancestors," aware of "the vulnerability of cross-historical contacts" (260), and forewarned that "connections across time [can] be forged out of fear and erotic torments" (261). It is in the context of such "negative affects" and with the desire to summon what Ann Cvetkovich has called "an archive of feelings" that I wish to consider suicidals and thoughts of suicide in relation to shame and queerness. Beyond the fact that such thoughts may be familiar - though not defining - features of queer lives, I wish to examine the essential queerness of suicide as a radical gesture in opposition to production and reproduction. Although I suggest throughout that shame and suicide may be linked, I also wish to be clear that I do not believe that the relation between them is merely causal.

Pompeia is a fin-de-siècle writer typically characterized by an "inquietação e desejo de álibi-fuga, de transfiguração simbólica” (Stegagno Picchio 424). His O ateneu (1888) is commonly read as a bildungsroman; however, I have argued recently against this. There is nothing particularly edifying, after all, about a novel motivated by an incendiary desire for revenge that ends with the destruction of the titular literary-pedagogical institution. As I see it, $O$ ateneu is primarily about shame. The novel highlights a particularly modern kind of vulnerability that derives from the professionalization of writing and democratization of the press. Lettered culture became increasingly violent during Pompeia's lifetime, and reputations suffered, particularly those of queer public figures. Evolutionary, criminal, and psychopathological theories of race and sexuality further stigmatized these people and gave support to the threat of public shaming. Pompeia repeatedly returned to issues of reputation and vulnerability in pieces published in some of the most important newspapers in Rio de Janeiro. 
An object of scrutiny and detraction on numerous occasions, Pompeia often scrambled to affirm and restore his reputation. These occasions include: Coelho Neto's malevolent remarks about Pompeia's supposed gynophobia; his alleged friends' insistence on his unstable personality_- "acessos de ciclotímico," in the words of Capistrano de Abreu (202), and "exagerada suscetibilidade mórbida," in those of Rodrigo Octávio (264); his passionate debates with other journalists; his unresolved duel with Olavo Bilac, who had publicly accused him of masturbation; and allegations that his fervent nationalism and defense of Floriano Peixoto were pathological. Octávio went so far as to claim in a letter (now located in the Arquivo do Centro de Estudos Afrânio Coutinho in Rio de Janeiro) that Pompeia's own doctor had confirmed that Pompeia's genitals were malformed by an "atrofia testicular dupla." Ultimately, as is well known, Pompeia shot himself in the chest on Christmas Day, 1895, leaving a suicide note that is a true speech act: "À Notícia e ao Brasil declaro que sou um homem de honra.” While his death cannot be reduced to the result of an unstable personality, it also cannot be seen as a necessary outcome of public shaming and denigration. Pompeia's final gesture can be read as self-fashioning, a performance of masculinity that relies on classical notions of honor suicide.

As in Europe, suicide was an object of concern and curiosity in Brazil in the 1890s. In his $O$ suicídio na capital federal (1894), criminologist Francisco Viveiros de Castro created four fluid, intangible categories of suicides unrelated to gender and race: insanity, "desgostos domésticos," drunkenness, and passions. He then organized 633 recent suicides and 925 attempted suicides into these groups, in order of decreasing frequency of occurrence (Castro 85). Among writers, suicide was associated with degeneration or "morbidity," and Pompeia's death only confirmed such suspicions for many observers. Others, however, asked disconsolately what could lead someone to an act of such extreme detachment. On the occasion of Pompeia's death, Machado de Assis noted the haunting illegibility of suicide: "Este velho tema renasce sempre que um homem dá cabo de si, mas é logo enterrado com ele, para renascer com outro. Velha questão, velha dúvida" (692). Pompeia himself had written about the subject several times. In a crônica in the Diário de Minas on 29 July 1888, he writes:

Como a razão íntima dos suicídios em geral. O suicida deixa uma carta. Disfarçando-se em explicações elucidantes, a carta pode 
bem ser o testamento cerrado de um segredo que ninguém descoserá. Então, quando expira sem mais, sem uma satisfação de respeito por essa miséria de humanidade, que talvez não o compreendesse. [...] Por que suicidou-se [Joseph Cailteau]? [...] Que trágica irritação fervia dentro daquelas aparências de calma? (Crônicas 22)

Like Machado, Pompeia leaves his reader with the idea of suicide as an ultimately unanswerable question.

The unreadability of both the act and the actor/victim of suicide recall Freud's formulation of melancholia. Freud observed that "the inhibition of the melancholic seems puzzling to us because we cannot see what it is that is absorbing him so entirely" (244). And according to Freud, not only is it difficult or impossible to read the causes of melancholia from the outside, the melancholic cannot read them, either, cannot identify the origin of the "diminution of his selfregard" (246) that brings about a "profoundly painful dejection, cessation of interest in the outside world, loss of the capacity to love, inhibition of all activity, and a lowering of the self-regarding feelings to a degree that finds utterance in self-reproaches and self-revilings, and culminates in a delusional expectation of punishment" (244). Darcy C. Buerkle has suggested that "Freud and his followers [...] made no argument for the escapability of melancholia, only for a mitigation of its effects" (134). Given this, she goes on to adds that "[s]uicide, under such circumstances, we learn — or can extrapolate-from psychoanalysis, need not, must not, cannot name its cause" (134). And yet, even though such private feelings seem to resemble deeply felt shame, according to Freud "[f]eelings of shame in front of other people [...] are lacking in the melancholic, or at least they are not prominent in him" (247). In fact, Freud argues that "[o]ne might emphasize the presence in him of an almost opposite trait of insistent communicativeness which finds satisfaction in self-exposure" (247).

Both Machado and Pompeia were more interested in the philosophical and existential aspects of suicide than its motives. The idea of death gave Pompeia sexual pleasure, perhaps even jouissance: "A ideia da morte é um afrodisíaco poderoso. Observa-se, nas grandes cidades, que as meninas das vizinhanças dos cemitérios são as mais atiradas ao namoro" (Stegagno Picchio 425). Elsewhere he asks: "Homens que lutais pela vida, quereis gozar? Quereis viver intensamente 
pelo estômago, pelo amor? Fúnebre ambição de suicidas!" (Obras 10). Pompeia thus turns Charles Darwin's and Max Nordau's theories on their head, making the struggle for life, the instinct of self-preservation (the stomach), and the instinct of preservation of the species (love) into the purview of suicide. He associates desire and autonomy with the power of self-extinction.

One cannot help but read Pompeia's suicide on Christmas Day as part of a performance calculated to turn acts of shaming into a spectacular display of masculine honor. Almost thirty years later, another Brazilian writer, Roberto Luís Eduardo Ribeiro Gomes (b. 12 Jan. 1882) would kill himself in a strikingly similar manner: he also shot himself in the chest, but this time on New Year's Eve, 1922. On the occasion of Gomes's death, Paratodos magazine published the following notice: "Roberto Gomes, tão fino, tão bom, que realizou na vida aquela pobre verdade de La Fontaine: 'Os delicados são infelizes ...' e que, com um tiro no coração, pôs termo ao seu destino na última noite do ano velho" (6 Jan. 1923).

\section{Roberto Gomes's New Year's Eve}

I first came across Gomes in a memoir by the (presumably heterosexual) painter Emilio di Cavalcanti that describes his introduction to literary culture through a homosexual family friend: "minha mãe, que era amiga de todos os intelectuais de sua época, apresentou-me, para que me guiasse, a Roberto Gomes, homem finíssimo, educado na Europa, meio francês. Verdadeiro tipo de literatura 'fin de siècle' e homosexual." According to Cavalcanti, Gomes "suicidou-se com a calma de um grego da decadência" (75). I looked further into Gomes's life and work and discovered that, although little has been written about him, he was a highly respected young playwright during the Brazilian Belle Époque, perhaps second only to João do Rio. ${ }^{3}$ His mother, Blanche Ribeiro Gomes, was French, and he grew up in Paris. He later wrote and staged a number of works in French. ${ }^{4}$

\footnotetext{
${ }^{3}$ Among recent critical work on Gomes, I am aware of Medeiros, Costa, and Borges.

${ }^{4}$ Roberto Luís Eduardo Ribeiro Gomes (1882-1922) was the son of Luiz Gomes Ribeiro and Blanche Ribeiro Gomes. He studied humanities at the Lycée Jaison de Sally. When he was fifteen years old, he and his parents returned to Brazil. He wrote about music and theater for the Rio de Janeiro newspapers A Notícia, A Gazeta de Notícias, and O Imparcial, sometimes under the pseudonyms Sem and Bemol. He also wrote short stories, such as "Os camondongos," about two
} 
Among Gomes's better-known plays are Ao declinar do dia (1910), O canto sem palavras (1912), Inocência (1915, first staged in 1921), based on Alfredo d'Escragnolle Taunay's novel of the same name, and Berenice (ca. 1916-18). Berenice was first staged in Paris in 1923, after the playwright's death. It was first staged in Portuguese in the 1940s, and in 1979, it was adapted for Globo network's series "Palco," with Teresa Raquel starring as Berenice. Gomes's contemporaries described him in terms almost identical to those that had described Pompeia. According to Afonso Arinos, "parecia entregue a certo descontrole nervoso, que se manifestava por intensa agitação. [...] Tudo aquilo se me afigurava esquisito, opressivo, doentio" (196). A recent critic of Symbolist theater has noted that his peers called him "adepto de gostos socráticos" (Fraga 173). As for Gomes himself, he expressed an affinity for João do Rio, who, incidentally, was the same age and died one year earlier. About João do Rio's Psicologia urbana, Gomes wrote: "Não penso que seja uma extravagância afirmar-se que a beleza dos livros reside em grande parte no espírito daqueles que os lêem. E, quanto à Verdade por que não viria a ser, afinal um colossal novelo de ilusões" (Gazeta de Notícias, 3 Mar. 1912). He was also known, and sometimes mocked, for his love of animals - he was Vice-President of the Brazilian Society for the Protection of Animals - especially dogs, which he talked about in famous speeches. He stated that "[q]uanto mais conheço os homens, mais amo os cães," and explained that he loved their meaningful silence because "[n]ós só falamos quando não temos nada que dizer." At the beginning of Gomes's Berenice, a character eloquently condemns animal abuse.

Gomes's works deal with silence, solitude, impossible loves, and a lack of faith in both humanity and futurity. Ao declinar do dia, for example, is about a woman with a dead child and a dying husband, and yet she still does not accept her lover's insistent marriage proposal. The protagonist of $O$ canto sem palavras realizes that he is in love with his stepdaughter, who is engaged to another man, and so he flees to Europe. Some of Gomes's plays have an even thinner plotline:

women who belong to a "grupo imenso das criaturas que não têm amigos nem inimigos, e que nascem, sem deixar nesta terra vestígios da sua passagem" (Illustração Brasileira, 1 Jan. 1915).

${ }^{5}$ Gomes gave the speech "Os cachorros e o amor canino" at the Instituto Nacional de Música on 29 August 1907 (Correio Paulistano, 30 Aug. 1907). This speech was later published in A Evolução. On 12 June 1919, he gave another speech about dogs, "Nossos irmãos, os cães," at the Associação dos Empregados no Comércio, on behalf of the Sociedade Brasileira Protetora dos Animais. 
A bela tarde revolves around a young woman and her uncle who lament their shared history of rejection and abandonment. $O$ sonho de uma noite de luar: noturno em um ato (1916), his most ethereal play, is about a man obsessed with his lover's photograph although he ignores her when she is right in front of him. In O jardim silencioso, a family gathers to discuss rumors about their adulterous mother; at the end of the play, she is shot by her lover. As in Taunay's 1872 novel, the female protagonist of Inocência is engaged to marry, but she falls in love with another man. Her fiancé kills her lover and then she also dies, but her name lives on when a rare and exotic butterfly is named after her. When Berenice, the eponymous protagonist of Gomes's final play, is betrayed by the much younger lover she had supported financially, she commits suicide. In short, Gomes's plays are very literary: nothing much happens, and nothing much is said. They are dream-like and somber, typically decadent in style, and they tend to feature frivolous characters.

It is not my intention to rescue Gomes from his silence, and it would probably be useless to try. We can attempt to extract some queer utopian meaning from isolated quotes from his plays, such as: "Laura, os preconceitos antigos que nos separavam outrora já não existem hoje . . . não existirão amanhã” (Ao declinar 59). But, overall, Gomes's works refuse to address us, and they depict silence as the only experience worth sharing: "Vivíamos num jardim silencioso, onde ninguém ousava falar. [...] Oh! Esse mundo de silêncio que todos carregam em si!" (O jardim silencioso 201). ${ }^{6}$ His wealthiest characters have no hope of community or a future.

In reading these (largely unreadable and unbearable) plays, it is important to recall Love's warning against interpreting their silent refusal as a cry for help from the queer past or the forgotten page. We must avoid a trap that is the exact opposite of the siren song that tormented Ulysses. As one of his titles announces, Gomes's song is a "canto sem palavras"; it does not want to allure us, no matter

\footnotetext{
${ }^{6}$ In addition to Gomes's speeches, poetry, and short fiction, newspapers of the time also mention a number of other plays: Le papillon (1897-98), Alanguissement, Le soir dans la chambre, Le promeneur solitaire (Fraga 18), O beijo ao luar (mentioned in Careta, 12 Apr. and 17 May, 1913), Ao Léo das ondas (mentioned in Fon fon, 10 Aug. 1918). Gomes also played the piano and acted. Sábato Magaldi includes Gomes in the chapter "Sensibilidades crepusculares" (179-80), along with Goulart de Andrade (1881-1936), João do Rio (1881-1921), and Paulo Gonçalves (1897-1927). Magaldi is rather generous in his claim that $O$ canto sem palavras "equals the best moments in the novels of Machado de Assis" (187). According to Eudinyr Fraga, Gomes's masterpiece is A bela tarde (154).
} 
how much we might want to be seduced by it. It gives us no positive genealogy that we can redeem or be redeemed by, no communication, no community, and no future. As Love has asked: "what if some historical texts express resistance to future readers and to the very idea of community?" ("Emotional Rescue" 262). In other words, these plays give us no opportunity to forge an attachment to their dead author, except perhaps for shared detachment. Moreover, and even though I do not share Gomes's class and racial attachments, I do not want to give up on both reclaiming and resisting his work, which comprises the kind of silent, silenced, suicidal archive that tends to encourage "bad" or "wounded attachments" to the past (Brown). As Love concludes with Foucault, "what happens in the archive is an encounter with historical violence, which includes both physical injury and the violence of obscurity, or annihilation from memory" (271). I would thus like to suggest that if we can hear Gomes's silence, it is through "a shared experience of social violence" (274). Any encounter with the queer archive must be read in half-hidden, shaded regions of the past, especially those that reflect what Pompeia called the ominous ambitions of suicides. Or, in the ambivalent words of Helena from $O$ jardim silencioso: "Não é a luz gloriosa do sol. É uma pobre luz cinzenta e triste. Mas é preferível às trevas em que agonizávamos. [...] Ah! Pai! Sofri, sofri tanto, sentia-me por vezes tão desanimada que desejava morrer.... Ah! Sim.... Morrer! Agora podemos chorar juntos [...] já é uma felicidade" (202).

\section{Towards an Archive of Suicidals}

The first book that I remember reading as a young adult, Hermann Hesse's 1927 novel Steppenwolf, was given to me by my father. The book made a deep impression on the queer adolescent I was becoming, but it was not the passages on sexuality that captured my attention. Instead it was the "Treatise on the Steppenwolf: Not for Everybody," which is about suicide (Hesse himself had attempted suicide in 1892, just days before his fifteenth birthday). The Treatise makes a curious distinction, which I found liberating at the time, between "suicides by accident" and "suicides by inclination" (an ironic rendering of the Lombrosian distinction between born and occasional criminals which, as we have seen, resurfaced in Candido's "radicais de ocasião"). According to the narrator, "suicides by inclination" may never actually kill themselves but are "marked by 
the belief that suicide is their most probable manner of death" (47). Harry Haller, the novel's protagonist, finds consolation "in the idea that the way to death was open to him at any moment. [...] He gained strength through familiarity with the thought that the emergency exit stood always open" (48-49). And yet, the fictional author of the Treatise adds that "all suicides have the responsibility of fighting against the temptation of suicide" (49). He explains that although Harry was an outsider, he never fully disengaged from his social class, in a way that recalls the location of decadents and flaneurs in the fin de siècle: "[i]t pleased him to set himself outside it, with his little vices and extravagances, as a queer fellow or a genius, but he never had his domicile in those provinces of life where the bourgeoisie had ceased to exist" (51). ${ }^{7}$ Nothing in the text implies that the suicidal "temperament"-if such a thing exists (and again, this vocabulary is typical of the fin de siècle) — is determined by class. Rather, one of the things that characterizes the suicidal (or decadent, for that matter) as queer is an ambivalent refusal to take up membership in the same social class upon which the suicidal depends.

For a long time, I have avoided writing about suicide, and especially its association with queerness. I do not underestimate the moral and biopolitical implications of this association, which reeks of nineteenth-century psychopathology. Indeed, as Sylvia Molloy reminds us, "the sleazy suicide of the pathetic queer is a fiction of homophobic discourse" (190). And yet, I have been repeatedly drawn to the so-called voluntary deaths of various queer subjects, particularly but not only during Brazil's long fin de siècle and Belle Époque. I have been haunted by the suicides of queer, sexually or racially stigmatized, shame-prone subjects, even if these deaths were not always confirmed suicides. These subjects include Pompeia (1863-95); the black abolitionist writer and engineer André Rebouças (1838-98); the US-born, naturalized Brazilian geologist Orville Adalbert Derby (1851-1915); the painter Gaspar Puga Garcia (18??-1914); Roberto Gomes (1882-1922); the inventor Alberto Santos-Dumont (1873-1932); the ethnologist Buel Quain (1912-39) (and Bernardo Carvalho's fictionalized version of his suicide in the novel Nove noites (2002)); the AfroBrazilian singer Elsie Houston (1902-43); the samba composers Evaldo Rui

\footnotetext{
${ }^{7}$ In the original German, Harry is described as a "Sonderling," which was translated as "queer fellow" in English and "esquisitão" in Portuguese.
} 
(1913-54) and Assis Valente (1911-58); the soccer player Manoel Anselmo da Silva, known as Maneco (1922-56); the architect Lota de Macedo Soares (191067), best known for her relationship with the poet Elizabeth Bishop; the writers Torquato Neto (1944-72), Pedro Nava (1903-84), and Ana Cristina César (195283); the singer and composer Júlio Barroso (1953-84); and the pioneering gay rights advocate Rosely Roth (1959-90). But I have never been particularly interested in or convinced by the supposed reasons that these figures chose to end their lives-personality, failing health, emotional or financial problems, etc. Instead, I am interested in sketching a cast of suicidals that inhabits a hypothetical queer archive of writings, thoughts, and feelings, regardless of the actual circumstances of their final days. And to the extent that thoughts of suicide may be familiar to all queer subjects (are they?), I want to suggest that suicidals are always located in the neighborhood of queerness and stigma, often embodied in the figures of the genius and the scapegoat. This archive of suicidals therefore includes: the poet Francisco Lobo da Costa (1853-88); the composer Francisco Magalhães do Valle (1869-1906); the poet Francisca Júlia (1871-1920); the writer and journalist Sylvia Serafim Thibau (1902-36); the cartoonist Péricles de Andrade Maranhão (1924-61), who meticulously rehearsed his spectacular death that also took place on New Year's Eve; or most recently, the young novelist Victor Heringer (1988-2018), and the young poet Ray Cruz (1996-2018). ${ }^{8}$

The fact that this archive is open exclusively to Brazilian suicidals is only partly affective; by locating them in a given national context, I wish to denaturalize their place in Brazilian culture and identity. My focus on fin-desiècle "suicide texts and suicide archives" and their potential cultural and "political resonances" (Gupta 13) is an attempt to identify queer writers who do not fit comfortably in the national and nationalist canon, and to make "strange fellowships" of "the isolated, the abject, [and] the shamed" (Dinshaw 204). I want to invoke the queerness of Manuel Bandeira's famous poem-testament that imagines his last poem will have "[a] paixão dos suicidas que se matam sem

\footnotetext{
${ }^{8}$ One recurring explanation for rumored suicides is that the deceased accidentally fell out of a window. Buerkle has shown how Émile Durkheim effaced the July 1886 suicide of his dear friend Victor Hommay with his description of Hommay's death: he "sat on the edge of a very low window without a balcony, which easily induced vertigo. He made a sudden and foolhardy movement, characteristic of him, and lost his balance" (qtd. in Buerkle 98). Durkheim was writing On Suicide (1897) at the time he wrote his tribute to Hommay. The press similarly reported that both Júlio Barroso and Victor Heringer fell from a balcony.
} 
explicação" (223). And although Carlos Drummond de Andrade, who has been known to express the occasional homophobic opinion, might seem an unlikely candidate for a queer archive of suicidals, I imagine him appearing at its edge, in the uncomfortable company of Pedro Nava. After all, on the occasion of Nava's suicide (after he supposedly received a phone call threatening to expose his bisexuality), Drummond wrote "Farewell," a poem that likens homosexuality to suicide as an act against nature: "o ato que não ousamos nem sabemos ousar [...] o não previsto nas leis da amizade e da natureza" (1405-06). Elsewhere Drummond has approached the queer archive from an oblique angle, as in the poem "Meninos suicidas," which declares "contam que nós é que morremos e são eles que nos mataram" (741), but also more directly, as in "Homenagem," a tribute to an archive of notorious suicides that includes a number of queer writers. In this poem, Drummond choreographs these individuals on the page such that each is in solitary isolation, and yet there is an overall suggestion of some sort of relation and community:

$\begin{array}{lll}\text { Jack London } & \text { Vachel Lindsay } & \text { Hart Crane } \\ \text { René Crevel } & \text { Walter Benjamin } & \text { Cesare Pavese } \\ \text { Stefan Zweig } & \text { Virginia Woolf } & \text { Raul Pompeia } \\ & \text { Sá Carneiro } & \end{array}$

E disse apenas alguns

De tantos que escolheram

O dia a hora o gesto

o meio

a dis-

solução (758)

Albert Camus famously wrote that " $\mathrm{t}] \mathrm{h}$ here is but one truly serious philosophical problem, and that is suicide" (495). Camus continued: "I am not interested in philosophical suicide, but rather in plain suicide. I merely wish to purge it of its emotional content and know its logic and its integrity" (533). In contrast to Camus, I am not interested in "plain suicide," or the general, philosophical problem of the meaning of life and death; instead, I am interested in the affective and queer dimension of suicide. Unlike Simon Critchley, who claims in his recent 
Notes on Suicide that he looks at it "from the point of view of those who have made the leap" (11), I write from the perspective of the survivors that we are. I am more concerned with the queer lives and afterlives of those who have always lived on the edge, long before the leap that becomes a dis-solução, in Drummond's terms. Indeed, Drummond's poem — who would have thought?indicates the openness and incompleteness of a hypothetical queer archive of "alguns de tantos que escolheram" suicide, in which community and relationships are comprised of blank distances that never come too close or stray too far from each other. In other words, as Buerkle has suggested, "for the survivor, suicide is an event without end" (x). And this is why "[s]uicide retains its searing radicality in spite of efforts to contain it" (Buerkle 3).

\section{What Now?}

To be very clear: by reclaiming and somehow dignifying the suicidal, I do not mean to suggest that suicide prevention (not to mention gun control) is unnecessary. My essay is not a suicidological study, and it does not focus on suicide as a social problem to be solved. I am, however, aware of the alarming growth in suicide rates in the twenty-first century in both Brazil and the US, and yet, I believe that an affirmative rhetoric of hope and community is not sufficient for us to understand and cope with totally negative moments and figures, those that reject social life, communication, and ultimately, futurity. ${ }^{9}$ The tendency to withdraw recalls other experiences of shame-prone subjects: mortification, selferasure, and a recurring desire to disappear. In this sense, a return to fin-de-siècle literature ceases to be a concern with periodization and becomes a queer identification comprised of various modes of melancholic detachment: from life, from history, from politics, from meaning, and from the present. ${ }^{10}$

I have no desire to make judgements, that is, I am not concerned with the moral or legal implications of suicide (and there is already a long philosophical tradition, from John Donne to David Hume and beyond, to address these issues). In a different context (namely, neoliberalism), Rusthon argues that "fictional

\footnotetext{
${ }^{9}$ See, for example, Greenhouse, Whitaker, and Timerman.

${ }^{10}$ Perhaps a distinction can be made between suicide as a mode and suicidal behavior more broadly speaking. For example, overdosing on alcohol or drugs and other forms of self-destruction share suicide's negativity but are not exactly conscious acts of suicide.
} 
narratives of suicidal depression can disrupt neoliberal approaches to wellbeing: whereas non-fictional narratives of severe, chronic, and suicidal depression are structurally bound to expectations of progress and recovery, fictional narratives are not bound to such structural predictability—it is, to use Russian Formalist terms, a story without a plot (196). Thus, my study of the literary-discursive figure of the suicidal - and the affective identification that I suggest, which is external to the dichotomy natural/unnatural death-aims to situate suicide outside of the framework of victimization, sacrifice, or scapegoating. Suicide has traditionally been defined by intentionality and conscious choice, and it has been read as a very specific performance, usually a performance of masculinity.

Recent critics, like Faubert and Buerkle, have noted that representations of heroic suicide, and particularly honor suicide, are often marked by class but also gender such that female suicide and queer suicide become unreadable outside of a set of prescriptive causes and triggering motives. To some extent, I agree with Critchley that suicide often has the effect of reorganizing the life that preceded it, investing that life with new meanings and normalizing the biography: "Suicide might grant life coherence, but only by robbing it of complexity by viewing it through the instant of one's death. Suicide saddens the past and abolishes the future" (66). Such coherence, however, is never complete, as suicide always generates more questions than answers. Thus, by situating the suicidal outside of the contingencies of the single event of death, that is, by situating the suicidal before or separate from the fact of attempted suicide (if that is possible), we remove the life narrative from solitary isolation, without effacing individual experience, and include it in a collective, iterative, but never linear narrative. Rather than excluding suicide from the queer archive, dispelling memories and histories of queer suicide, or trying to dissociate suicide from queerness, I have explored in this essay the rhetorical deployment of suicide in the development of new forms of affirmative escapism or perhaps negative utopianism for those times when the present and future seem unbearable.

\section{Works Cited}

Abreu, Capistrano de. Correspondência de Capistrano de Abreu, edited by José Honório Rodrigues, Civilização Brasileira, 1977.

Aching, Gerard. The Politics of Spanish American Modernismo: By Exquisite 
Design. Cambridge UP, 1997.

Anderson, Amanda. The Powers of Distance: Cosmopolitanism and the Cultivation of Detachment. Princeton UP, 2001.

Andrade, Carlos Drummond. Poesia completa. Nova Aguilar, 2002.

Antelo, Raúl. "Introdução.” A alma encantandora das ruas: crônicas de João do Rio. Companhia das Letras, 2008, pp. 7-17.

—. João do Rio: o dândi e a especulação. Livrarias Taurus-Timbre, 1989.

Arinos, Afonso. Planalto. José Olympio, 1968.

Assis, Joaquim Maria Machado de. Machado de Assis: obra completa. Nova Aguilar, 1997.

Bandeira, Manuel. Poesia completa e prosa. Nova Aguilar, 1977.

Borges Junior, Eli. "Roberto Gomes e as tentativas de modernização do teatro brasileiro." Revista Sala Preta, vol. 15, no. 1, 2015, pp. 112-23.

Bojunga, Lygia. O meu amigo pintor. Casa Lygia Bojunga, 2006.

Bourget, Paul. "Baudelaire and the Decadent Movement." Symbolist Art Theories: A Critical Anthology, edited by Henri Dorra, U of California P, 1994, pp. 128-31.

Braga-Pinto, César. A violência das letras: amizade e inimizade na literatura brasileira (1888-1940). U Estadual do Rio de Janeiro, 2018.

Brown, Wendy. "Wounded Attachments." Political Theory, vol. 21, no. 3, 1993, pp. 390-410.

Buerkle, Darcy C. Nothing Happened: Charlotte Salomon and an Archive of Suicide. U of Michigan P, 2013.

Camus, Albert. "The Myth of Sisyphus." The Plague, The Fall, Exile and the Kingdom, and Selected Essays, translated by Justin O'Brian. Everyman's Library, 2004.

Candido, Antonio. "De cortiço a cortiço." O discurso e a cidade. Duas Cidades and Ouro sobre Azul, 2004, pp. 105-29.

—. "Literatura e cultura de 1900 a 1945 (panorama para estrangeiros)." Literatura e sociedade. Companhia Editora Nacional, 1980, pp. 109-38.

—. "Radicais de ocasião." Teresina etc. Paz e Terra, 1980, pp. 83-94.

Carvalho, Bernardo. Nove noites. Companhia das Letras, 2002.

Cavalcanti, Emilio di. Viagem da minha vida. Civilização Brasileira, 1955.

Costa, Marta Morais. "A dramaturgia de Roberto Gomes, da Casa fechada à abertura modernista.” Revista Letras, no. 60, 2003, pp. 259-74. 
Crimp, Douglas. Melancholia and Moralism: Essays on AIDS and Queer Politics. Massachusetts Institute of Technology P, 2002.

Critchley, Simon. Notes on Suicide. Fitzcarraldo, 2015.

Cruz, Ray. O que é a vida senão uma sucessão de suicídios? Appaloosa, 2018.

Cvetkovich, Ann. An Archive of Feelings: Trauma, Sexuality, and Lesbian Public Cultures. Duke UP, 2003.

Dimas, Antonio. “A encruzilhada do fim do século." América Latina: palavra, literatura e cultura, edited by Ana Pizarro, Fundação Memorial da América Latina, pp. 535-74.

Dinshaw, Carolyn. "Got Medieval?" Journal of the History of Sexuality, vol. 10, no. 2, 2001, pp. 202-12.

Edelman, Lee. No Future: Queer Theory and the Death Drive. Duke UP, 2004.

El Far, Alessandra. Páginas de sensação: literatura popular e pornográfica no Rio de Janeiro (1870-1924). Companhia das Letras, 2004.

Faubert, Michelle. "Introduction: Romanticism and Suicide." Literature Compass, vol. 12, no. 12, pp. 641-51.

Fraga, Eudinyr. O simbolismo no teatro brasileiro. Art \& Tec, 1992.

Franco, Afonso Arinos de Melo. Planalto. J. Olympio, 1968.

Freud, Sigmund. "Mourning and Melancholia." The Standard Edition of the Complete Psychological Works of Sigmund Freud, Volume XIV (19141916): On the History of the Psycho-Analytic Movement, Papers on Metapsychology and Other Works, translated by James Strachey, Hogarth P, 1964 (1917), pp. 237-58.

Glick, Elisa. "Turn-of-the-Century Decadence and Aestheticism." The Cambridge History of Gay and Lesbian Literature, edited by E.L. McCallum and Mikko Tuhkanen, Cambridge UP, 2014, pp. 325-43.

Gomes, Roberto. Teatro de Roberto Gomes, edited by Marta Morais da Costa, Instituto Nacional de Artes Cênicas, 1983.

Goulemot, Jean Marie. Ces livres qu'on ne lit que d'une main: lecture et lecteurs de livres pornographiques au XVIIIeme siècle. Alinea, 1991.

Greenhouse, Emily. "The Neglected Suicide Epidemic." The New Yorker, 13

Mar. 2014, www.newyorker.com/news/news-desk/the-neglected-suicideepidemic.

Gupta, Suman, et al. Usurping Suicide: The Political Resonances of Individual Deaths. Zed, 2017. 
Hardman, Francisco Foot. Nem pátria, nem patrão! U Estadual Paulista, 2002. Hesse, Hermann. Steppenwolf, translated by Basil Creighton, Picador, 2002. Jameson, Fredric. The Political Unconscious: Narrative as a Socially Symbolic Act. Cornell UP, 1981.

Love, Heather. "Emotional Rescue." Gay Shame, edited by David M. Halperin and Valerie Traub, U of Chicago P, pp. 256-76.

-. Feeling Backward: Loss and the Politics of Queer History. Harvard UP, 2007.

—. "Introduction: Modernism at Night." PMLA, vol. 124, no. 3, May 2009, pp. 744-48.

Magaldi, Sábato. Panorama do teatro. Global, 2014.

Medeiros, Elen de. "Formas crepusculares, dores silencionas: o teatro simbolista de Roberto Gomes." Pitágoras 500, vol. 1, no. 1, October 2011, pp. 22-39.

Molloy, Sylvia. "Too Wilde for Comfort: Desire and Ideology in Fin-de-Siècle Spanish America." Social Text, no. 31/32, 1992, pp. 187-201.

Muñoz, José Esteban. Cruising Utopia: The Then and There of Queer Futurity. New York UP, 2009.

Octávio, Rodrigo. Minhas memórias dos outros: última série. José Olympio, 1936.

Pompeia, Raul. Crônicas do Rio, edited by Virgílio Moreira, Secretaria Municipal de Cultura, 1982.

—. Obras, edited by Eduardo de Faria Coutinho, Civilização Brasileira, 1983.

Prado, Antonio Arnoni. "Nacionalismo literário e cosmopolitismo." América Latina: Palavra, Literatura e Cultura, edited by Ana Pizarro, vol. 1, Fundação Memorial da América Latina, pp. 599-613.

Price, Matthew Burroughs. "A Genealogy of Queer Detachment.” PMLA, vol. 130 , no. 3, 2015, pp. 648-65.

Ramos, Julio. Desencuentros de la modernidad en América Latina: literatura y política en el siglo XIX. Fondo de Cultura Económica, 1989.

Robbins, Bruce. "Introduction Part I: Actually Existing Cosmopolitanism." Cosmopolitics: Thinking and Feeling Beyond the Nation, edited by Pheng Cheah and Bruce Robbins, U of Minnesota P, 1998, pp. 1-19.

Rushton, Amy. "A Bubble in the Vein: Suicide, Community, and the Rejection of Neoliberalism in Hanya Yanagihara's A Little Life and Miriam Toews's All My Puny Sorrows." World Literature, Neoliberalism, and the Culture of 
Discontent, edited by Sharae Deckard and Stephen Shapiro, Palgrave Macmillan, 2019, pp. 195-213.

Siskind, Mariano. Cosmopolitan Desires: Global Modernity and World Literature in Latin America. Northwestern UP, 2014.

Stegagno Picchio, Luciana. História da literatura brasileira. Nova Aguilar, 1997.

Timerman, Natália. "O suicídio e o escritor," Coluna Desha, 24 Sept. 2018, coluna.desha.com.br/o-suicidio-e-o-escritor-natalia-timerman/.

Viveiros de Castro, Francisco. O suicídio na capital federal: estatística de 1870 a 1890. Imprensa Nacional, 1894.

Whitaker, Robert. "Suicídio na era do Prozac.” Mad in Brazil, 10 Oct. 2018, madinbrasil.org/2018/09/suicidio-na-era-do-prozac/. 